\title{
Herbivorous arthropod community of an alien weed Solanum carolinense L.
}

\author{
Osamu IMURA ${ }^{\dagger}$ \\ Division of Entomology, National Institute of Agro-Environmental Sciences; Tsukuba, Ibaraki 305-8604, Japan \\ (Received 18 September 2002; Accepted 12 March 2003)
}

\begin{abstract}
Herbivorous arthropod fauna of the horse nettle Solanum carolinense L., an alien solanaceous herb of North American origin, was characterized by surveying arthropod communities in the fields and comparing them with the original community compiled from published data to infer the impact of herbivores on the weed in the introduced region. Field surveys were carried out in the central part of mainland Japan for five years including an intensive regular survey in 1992. Thirty-nine arthropod species were found feeding on the weed. The leaf, stem, flower and fruit of the weed were infested by the herbivores. The comparison of characteristics of the arthropod community with those of the community in the USA indicated that more sapsuckers and less chewers were on the weed in Japan than in the USA. The community in Japan was composed of high proportions of polyphages and exophages compared to that in the USA. Eighty-seven percent of the species are known to be pests of agricultural crops. Low species diversity of the community was also suggested. The depauperated herbivore community, in terms of feeding habit and niche on S. carolinense, suggested that the weed partly escaped from herbivory in its reproductive parts. The regular population census, however, indicated that a dominant coccinellid beetle, Epilachna vigintioctopunctata, caused a noticeable damage on the leaves of the weed.
\end{abstract}

Key words: Alien weed; Solanum carolinense; herbivorous arthropod community; community structure; feeding habits

\section{INTRODUCTION}

Many species of alien weeds have invaded Japan from overseas (Asai, 1993; Enomoto, 1999). These alien weeds often propagate abundantly and cause serious problems including yield loss of agricultural crops, threat to endemic plants, degradation of amenities and increased weed control costs.

Among the alien weeds, the horse nettle, Solanum carolinense L., is a perennial solanaceous herb of North American origin whose presence was initially recorded in 1906 in Japan (Asai, 1993). Recently, the weed has spread widely over agricultural fields, grasslands, roadsides, lawns, and abandoned areas, where $S$. carolinense forms dense populations. The weed is now present throughout almost all of Japan from the northern island, Hokkaido, to the southern island, Okinawa (Nishida, et al., 1999).

The proliferation of alien weeds can be accounted for by several factors, such as an absence of effective native herbivores or competitors, occu- pation of open niches, establishment in a more favorable environment than the native habitat, or greater fitness of aliens than endemics (Harper, 1965; Goeden, 1971a; Crawley, 1987; Cousens and Mortimer, 1995). However, these possible reasons are not mutually exclusive. The greater fitness or vigor of the aliens is often thought to be a result of the absence of effective native herbivores (enemy release hypothesis) (e.g. Blossey and Nötzold, 1995; Crawley, 1997; Tilman, 1999; Keane and Crawley, 2002).

Insect herbivore communities on alien plants have a different structure from those on the same plants in the native habitat (Strong et al., 1984). There is a possibility that such different structures of the herbivore communities on alien plants are related to the proliferation of alien weeds. In this paper, I characterize the herbivorous arthropod community associated with $S$. carolinense in Japan by surveying arthropod communities in the field and compare them with the native community to infer the impact of herbivores on the weed.

\footnotetext{
${ }^{\dagger}$ Present address: Division of Grassland Ecology, National Institute of Livestock and Grassland Science; Senbonmatsu 768, Nishinasuno, Tochigi 329-2793, Japan. E-mail: imurao@affrc.go.jp
} 


\section{MATERIALS AND METHODS}

Study sites. Arthropod herbivores of S. carolinense were surveyed at several sites in and around the National Institute of Agro-Environmental Sciences (NIAES), Tsukuba, Ibaraki Prefecture (lat. $36^{\circ} \mathrm{N}$, long. $140^{\circ} \mathrm{E}$ ). The survey was also carried out on $S$. carolinense populations along roadsides and in grasslands in the National Institute of Livestock and Grassland Science (NILGS), Nishinasuno, Tochigi Prefecture (lat. $37^{\circ} \mathrm{N}$, long. $140^{\circ} \mathrm{E}$ ). $S$. carolinense populations were naturally growing at these sites. The establishment of the weed populations in NIAES was quite possibly after 1980 when the institute moved there. S. carolinense in NILGS was first recorded in 1987. The two sites were located in the central part of the Japanese mainland.

Field survey. The ground area $(10 \mathrm{~m} \times 17 \mathrm{~m})$ at the NIAES site (Tsukuba) was separated into 170 $1 \mathrm{~m} \times 1 \mathrm{~m}$ square plots. The number of $S$. carolinense shoots (ramets) in each plot was counted once a week or every other week from May 27 to October 28 in 1992. Thirty shoots were randomly selected and the numbers of arthropod herbivores present on the shoots were counted (hereafter I refer the counting of the herbivores to the regular census). When feeding of the herbivores was not confirmed in the field, they were brought into the laboratory and reared on $S$. carolinense at $25^{\circ} \mathrm{C}$ to check their feeding trace, feces and/or molting. The herbivore fauna was also surveyed occasionally by visual inspections of $S$. carolinense populations in the area and the vicinities of NIAES and in NILGS from 1993 to 1996.

Literature survey. Information of herbivores on $S$. carolinense in the USA was collected by referring to the databases of $\mathrm{CAB}$ and BIOSIS, reference citations in related papers and correspondence with entomologists and plant scientists.

Data analyses. The $G$-test (Sokal and Rohlf, 1995) was performed to compare the frequencies of arthropod compositions in the communities. The species diversity index of the Shannon-Wiener function $\left(H^{\prime}\right)$ was calculated using the regular census arthropod data; $95 \%$ C.L. (confidence limit) of $H^{\prime}$ was estimated by the bootstrap procedure with 500 runs (Krebs, 1999).

\section{RESULTS}

\section{Arthropod community}

Thirty-nine herbivorous arthropod species were found feeding on $S$. carolinense (Table 1). The most abundant was homopterous species $(38 \%$ of the total number of species), followed by heteropterous species $(20.0 \%)$, coleopterous species $(12.8 \%)$, thysanopterous species $(12.8 \%)$ and lepidopterous species (10.3\%) (Fig. 1). Table 2 is a list of herbivorous arthropods of $S$. carolinense in the USA, the origin of the weed, which was compiled from miscellaneous literature. Although no studies have been conducted based on intensive faunal survey of the herbivorous arthropods feeding on $S$. carolinense in the USA, the list would represent a general character of the community in the place of origin. The ratio of homopterous species was larger $(G$-test, $p<0.01)$ and that of coleopterous species was smaller $(G$-test, $p<0.01)$ in the community of the introduced region than in that of the original site (Fig. 1). Tetranychus urticae was the only common species that was recorded in both Japan and the USA.

The majority of species (74\%) were sapsuckers including species in Homoptera, Heteroptera, Thysanoptera, and Acarina in Japan (Fig. 2). Leaf chewers were lepidopterous and coleopterous species. The ratio of sapsuckers was larger ( $G$-test, $p<0.01)$ and that of chewers was smaller ( $G$-test, $p<0.05$ ) in Japan than in the USA (Fig. 2). Among the lepidopterous species, there was one leaf roller. Those species were all exophages. The only endophagous species found was an agronomizid leaf miner, and neither stem borers nor gall formers were found on $S$. carolinense in Japan (Fig. 2). In the region of origin, however, endophagous species of two leaf miners and four stem and fruit borers were recorded (Table 2, Fig. 2). Additionally, the larvae of Furumenta nundinella bore into fruits to induce parthenocarpic development of the fruits in the manner of a gall former (Solomon, 1980). Thus, the endophagous species was relatively larger in the origin than in the introduced regional site $(G$-test, $p<0.05)$.

Nineteen, 17, seven and one species infested leaves, stems, flowers and fruits, respectively (Table 1). A coccinellid beetle, Epilachna vigintioctopunctata, which was a voracious leaf feeder (Imura and Ninomiya, 1998), caused some damage 
Table 1. Herbivorous arthropods associated with S. carolinense in Tsukuba and Nishinasuno, Japan

\begin{tabular}{|c|c|c|c|c|c|}
\hline $\begin{array}{l}\text { Order } \\
\text { Family }\end{array}$ & Species & $\begin{array}{c}\text { Feeding } \\
\text { stages }^{\mathrm{a}}\end{array}$ & $\begin{array}{l}\text { Feeding } \\
\text { habit }^{\mathrm{b}}\end{array}$ & $\begin{array}{l}\text { Associated } \\
\text { plant parts }^{\mathrm{c}}\end{array}$ & $\begin{array}{l}\text { Host range }^{\mathrm{d}} \\
\text { pest status }\end{array}$ \\
\hline \multicolumn{6}{|l|}{ Acarina } \\
\hline Tetranychidae & Tetranychus urticae Koch* & $\mathrm{I}, \mathrm{A}$ & $\mathrm{S}$ & $\mathrm{L}$ & $\mathrm{P} / \mathrm{Sol}$ \\
\hline Tetranychidae & Tetranychidae sp.\# & $\mathrm{I}, \mathrm{A}$ & $\mathrm{S}$ & $\mathrm{L}$ & $?$ \\
\hline \multicolumn{6}{|l|}{ Thysanoptera } \\
\hline Thripidae & Thrips hawaiiensis (Morgan) & $\mathrm{I}, \mathrm{A}$ & $\mathrm{S}$ & $\mathrm{F} 1$ & $\mathrm{P} / \mathrm{Sol}$ \\
\hline Thripidae & Thrips setosus Moulton* & $\mathrm{I}, \mathrm{A}$ & $\mathrm{S}$ & $\mathrm{L}$ & $\mathrm{P} / \mathrm{Sol}$ \\
\hline Thripidae & Frankliniella intonsa (Trybom) $)^{\#}$ & $\mathrm{I}, \mathrm{A}$ & $\mathrm{S}$ & $\mathrm{Fl}$ & $\mathrm{P} / \mathrm{Sol}$ \\
\hline Thripidae & Megalurothrips distalis (Karny) & $\mathrm{I}, \mathrm{A}$ & $\mathrm{S}$ & $\mathrm{F} 1$ & $\mathrm{P} / \mathrm{Oth}$ \\
\hline Phlaeothripidae & Haplothrips chinensis Priesner & $\mathrm{I}, \mathrm{A}$ & $\mathrm{S}$ & $\mathrm{Fl}$ & $\mathrm{P} / \mathrm{Sol}$ \\
\hline \multicolumn{6}{|l|}{ Heteroptera } \\
\hline Plataspidae & Megacopta punctatissimum (Montandon) & A & $\mathrm{S}$ & St & $\mathrm{P} / \mathrm{Oth}$ \\
\hline Pentatomidae & Eysarcoris ventralis (Westwood) & $\mathrm{A}$ & $\mathrm{S}$ & St & $\mathrm{P} / \mathrm{Oth}$ \\
\hline Pentatomidae & Plautia stali Scott & A & $\mathrm{S}$ & St & $\mathrm{P} / \mathrm{Sol}$ \\
\hline Coreidae & Acanthocoris sordidus (Thunberg)* & $\mathrm{I}, \mathrm{A}$ & $\mathrm{S}$ & $\mathrm{St}$ & $\mathrm{O} / \mathrm{Sol}$ \\
\hline Alydidae & Riptortus clavatus (Thunberg) & A & $\mathrm{S}$ & St & $\mathrm{P} / \mathrm{Oth}$ \\
\hline Lygaeidae & Piocoris varius (Uhler)* & $\mathrm{A}$ & $\mathrm{S}$ & St & $\mathrm{P} / \mathrm{Oth}$ \\
\hline Miridae & Adelphocoris variabilis (Uhler) & A & $\mathrm{S}$ & St, L & $\mathrm{P} / \mathrm{Oth}$ \\
\hline \multicolumn{6}{|l|}{ Homoptera } \\
\hline Cercopidae & Paracercopis assimilis (Uhler)* & A & $\mathrm{S}$ & $\mathrm{St}$ & $\mathrm{P} / \mathrm{Oth}$ \\
\hline Aphrophodiae & Aphrophora ishidae Matsumura & A & $\mathrm{S}$ & St & $\mathrm{P} / \mathrm{Non}$ \\
\hline Tettigellidae & Bothrogonia japonica Ishihara ${ }^{\#}$ & A & $\mathrm{S}$ & St & $\mathrm{P} / \mathrm{Oth}$ \\
\hline Tettigellidae & Cicadella viridis (Linnaeus) ${ }^{* \#}$ & A & $\mathrm{S}$ & St & $\mathrm{P} / \mathrm{Oth}$ \\
\hline Tettigellidae & Pagaronia sp.* & $\mathrm{I}, \mathrm{A}$ & $\mathrm{S}$ & St & $?$ \\
\hline Tettigellidae & Kolla atramentaris (Motschulsky)* & $\mathrm{I}, \mathrm{A}$ & $\mathrm{S}$ & St & $\mathrm{P} / \mathrm{Oth}$ \\
\hline Cicadellidae & Empoasca sp.* & $\mathrm{I}, \mathrm{A}$ & $\mathrm{S}$ & St, L & ? \\
\hline Cicadellidae & Balchutha rubrinervis (Matsumura)* & $\mathrm{I}, \mathrm{A}$ & $\mathrm{S}$ & $\mathrm{L}$ & $\mathrm{P} / \mathrm{Oth}$ \\
\hline Ricaniidae & Orosanga japonicus (Melichar)* & $\mathrm{I}, \mathrm{A}$ & $\mathrm{S}$ & $\mathrm{St}$ & $\mathrm{P} / \mathrm{Oth}$ \\
\hline Flatidae & Geisha distinctissima (Walker)* & A & $\mathrm{S}$ & $\mathrm{St}$ & $\mathrm{P} / \mathrm{Oth}$ \\
\hline Aleyrodidae & Trialeurodes vaporariorum (Westwood) ${ }^{* \#}$ & $\mathrm{I}, \mathrm{A}$ & $\mathrm{S}$ & $\mathrm{L}$ & $\mathrm{P} / \mathrm{Sol}$ \\
\hline Aphididae & Aphis gossypii Glover* & $\mathrm{I}, \mathrm{A}$ & $\mathrm{S}$ & $\mathrm{L}$ & $\mathrm{P} / \mathrm{Sol}$ \\
\hline Aphididae & Aulacorthum magnoliae (Essig et Kuwana)* & $\mathrm{I}, \mathrm{A}$ & $\mathrm{S}$ & $\mathrm{L}$ & $\mathrm{P} / \mathrm{Sol}$ \\
\hline Aphididae & Aulacorthum solani (Kaltenbach) ${ }^{* \#}$ & $\mathrm{I}, \mathrm{A}$ & $\mathrm{S}$ & $\mathrm{L}$ & $\mathrm{P} / \mathrm{Sol}$ \\
\hline Aphididae & Macrosiphum euphorbiae (Thomas)* & $\mathrm{I}, \mathrm{A}$ & $\mathrm{S}$ & $\mathrm{L}$ & $\mathrm{P} / \mathrm{Sol}$ \\
\hline \multicolumn{6}{|l|}{ Lepidoptera } \\
\hline Pyralidae & Udea testacea (Butler) & I & $\mathrm{R}$ & $\mathrm{L}$ & $\mathrm{P} / \mathrm{Oth}$ \\
\hline Geometridae & Ectropis crepuscularia (Deni et Schiff) & I & $\mathrm{C}$ & $\mathrm{L}$ & $\mathrm{P} / \mathrm{Oth}$ \\
\hline Arctiidae & Arctia caja phaeosoma (Butler) & I & $\mathrm{C}$ & $\mathrm{Fl}$ & $\mathrm{P} / \mathrm{Oth}$ \\
\hline Noctuidae & Agrotis segetum (Denis et Schiffermuller) & I & $\mathrm{C}$ & $\mathrm{L}, \mathrm{St}$ & S/Sol \\
\hline \multicolumn{6}{|l|}{ Coleoptera } \\
\hline Scarabaeidae & Blitopertha orientalis (Waterhouse)* & A & $\mathrm{C}$ & $\mathrm{L}$ & $\mathrm{P} / \mathrm{Oth}$ \\
\hline Scarabaeidae & Popillia japonica Newman $^{\#}$ & $\mathrm{~A}$ & $\mathrm{C}$ & $\mathrm{Fl}$ & $\mathrm{P} / \mathrm{Oth}$ \\
\hline Coccinellidae & Epilachna vigintioctomaculata Motschulsky*\# & $\mathrm{I}, \mathrm{A}$ & $\mathrm{C}$ & $\mathrm{L}$ & $\mathrm{P} / \mathrm{Sol}$ \\
\hline Coccinellidae & Epilachna vigintioctopunctata (Fabricius)* & $\mathrm{I}, \mathrm{A}$ & $\mathrm{C}$ & $\mathrm{L}, \mathrm{Fl}, \mathrm{Fr}$ & $\mathrm{O} / \mathrm{Sol}$ \\
\hline Chrysomelidae & Atrachya menetriesi (Faldermann) & A & $\mathrm{C}$ & $\mathrm{L}$ & $\mathrm{P} / \mathrm{Sol}$ \\
\hline \multicolumn{6}{|c|}{ 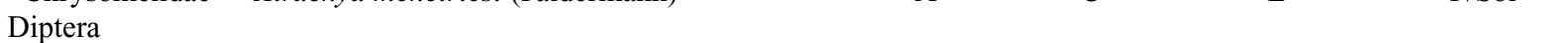 } \\
\hline Agromyzidae & Agromyzidae sp. & I & MI & $\mathrm{L}$ & $\mathrm{O} ?$ \\
\hline
\end{tabular}

* Species occurred in the regular census in 1992.

\# Species collected in NILGS, Nishinasuno.

${ }^{\text {a }}$ I: larva or nymph, A: adult.

${ }^{\text {b }}$ S: sapsucker, C: chewer, R: leaf roller, MI: leaf miner.

${ }^{c}$ L: leaf, St: stem, Fl: flower, Fr: fruit.

${ }^{\mathrm{d}} \mathrm{O}$ : specialist of solanaceous plants (oligophage); P: generalist which feeds on plants of Solanaceae and other plant families (polyphage), ?: host range not known.

' Sol: pests of solanaceous crops, Solanum melongena, Solanum tuberosum, Lycopersicum esculentum, Capsicum annuum and/or Nicotiana tabacum, Oth: pests of crops of other plant-families, Non: non pests. The host range and the pest status was based on Japanese Society of Applied Entomology and Zoology (1987). 

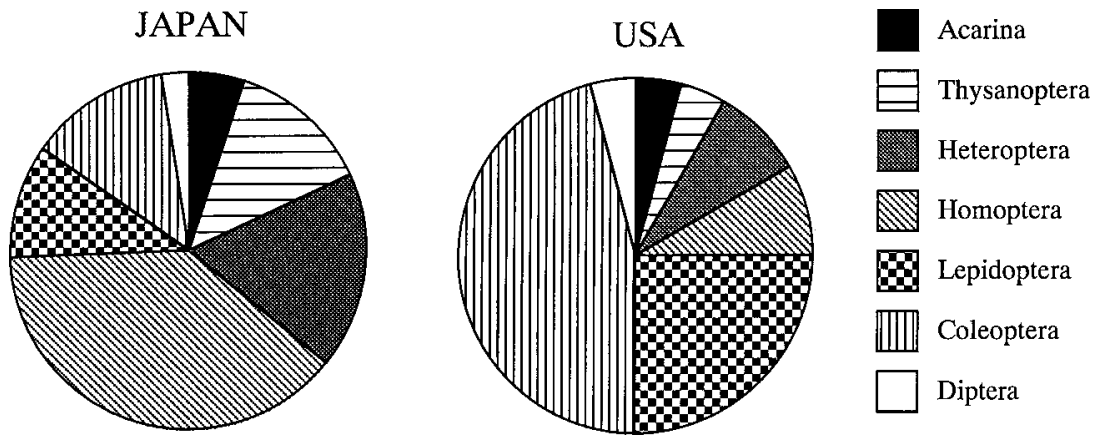

Fig. 1. Taxonomic composition of the herbivorous arthropod community on $S$. carolinense in the introduced region, Japan and in the region of origin, USA.

JAPAN

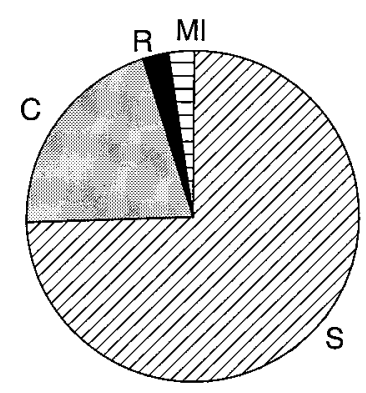

USA

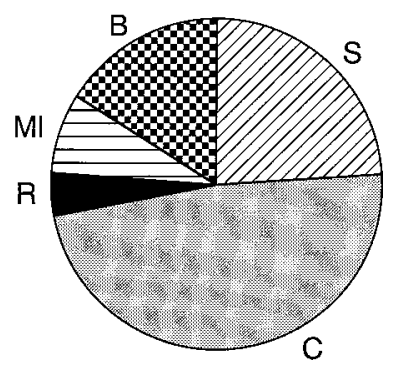

Fig. 2. Feeding habit of the herbivorous arthropod community on S. carolinense in the introduced region, Japan and in the region of origin, USA. S: sapsucker, C: chewer, R: leaf roller, MI: leaf miner, and B: stem borer.

on flowers by their infestation. Most of the thysanoptera species were flower feeders, and their damage on the flowers seemed to be slight. Three coleopterous species infest flowers in the original site (Table 2). Among the beetles, Anthonomus nigrinus was abundant on the plant growing in the flower buds (Burke, 1963). E. vigintioctopunctata also occasionally infested the surface of fruits (Table 1). In the USA, at least three species are described as fruit feeders (Table 2); sometimes a large proportion of the plant's fruits was infested by $F$. nundinella larvae, and the moth had a great impact on the fruit set (Solomon and McNaughton, 1979; Solomon, 1981). Two root feeders of flea beetles infested $S$. carolinense in the region of origin (Table 2), but no apparent root feeder was found in our fields, although the survey was mainly done for above ground fauna.

Hymenopterous species of Lasionglossum japonicum (Dalla Torre), Apis mellifera L., Ceratina flavipes Smith and Xylocopa appendiculata

circumvolans Smith (pollen collectors) and a dipterous species of Estrophe balteata deGeer (pollen feeder) were recorded visiting flowers of $S$. carolinense. Since pollen collectors and feeders are not often noticed as herbivores, they were not included in Table 1.

In the region of origin, F. nundinella and Leptinotarsa juncta were monophagous feeders of $S$. carolinense (Table 2) and Epitrix fuscula fed almost exclusively on $S$. carolinense (Wise and Sacchi, 1996) (monophages). Further, most other herbivores listed in Table 2 were oligophagous species feeding only on plants of the solanaceous family (oligophages). In the introduced area, there was no monophagous species that fed exclusively on $S$. carolinense (Table 1). Only E. vigintioctopunctata, a coreid bug Acanthocoris sordidus and probably an agronomyzid fly were specialized on Solanaceae plants (oligophages). The Major hosts of Epilachna vigintioctomaculata were from Solanaceae. All others were polyphages feeding on Solanaceae and other plant families. Fifty percent of the herbivores were opportunists that did not breed on $S$. carolinense, since no immature stage of the species was found infesting the weed (Table 1).

The community on $S$. carolinense shared $41 \%$ of its species with those of solanaceous crops (oligophages) and $46 \%$ of its species with those of other crops (polyphages) (Table 1); thus, $87 \%$ of the species were pest species of agricultural crops.

\section{Seasonal abundance and diversity of the arthro- pods in the regular census}

Phenology of $S$. carolinense in 1992 in the NIAES field was as follows. Several shoots of $S$. carolinense began to emerge on May 22 and the 
Table 2. Herbivorous arthropods recorded on S. carolinense in the USA, the origin of the weed, compiled from published references

\begin{tabular}{|c|c|c|c|c|c|}
\hline $\begin{array}{l}\text { Order } \\
\text { Family }\end{array}$ & Species & $\begin{array}{l}\text { Feeding } \\
\text { habit }^{\mathrm{a}}\end{array}$ & $\begin{array}{l}\text { Associated } \\
\text { plant part }^{\mathrm{b}}\end{array}$ & $\begin{array}{c}\text { Host } \\
\text { range }^{c}\end{array}$ & References $^{\mathrm{d}}$ \\
\hline \multicolumn{6}{|l|}{ Acarina } \\
\hline Tetranichidae & Tetranychus urticae Koch & $\mathrm{S}$ & $\mathrm{L}$ & $\mathrm{P}$ & 2 \\
\hline \multicolumn{6}{|l|}{ Thysanoptera } \\
\hline Thripidae & Thrips tabaci Lind. & $\mathrm{S}$ & $\mathrm{L}$ & $\mathrm{P}$ & 2 \\
\hline \multicolumn{6}{|l|}{ Heteroptera } \\
\hline Lygaeidae & Ischnodemus falicus Say & $\mathrm{S}$ & $\mathrm{L}$ & $\mathrm{P}$ & 1 \\
\hline Tingidae & Gargaphia solani Heid. & $\mathrm{S}$ & $\mathrm{L}$ & $\mathrm{P}$ & 1 \\
\hline \multicolumn{6}{|l|}{ Homoptera } \\
\hline Cicadellidae & Scaphytopius acutus (Say) & S & $\mathrm{L}$ & $\mathrm{O}$ & 11 \\
\hline Psyllidae & Paratrioza cockerelli (Sulc.) & $\mathrm{S}$ & $\mathrm{L}$ & $\mathrm{O}$ & 1 \\
\hline \multicolumn{6}{|l|}{ Lepidoptera } \\
\hline Sesiidae & Synanthedon rileyana (Hy. Edward) & $\mathrm{B}$ & St & $\mathrm{O}$ & 1 \\
\hline Gelechiidae & Frumenta nundinella Zeller & $\mathrm{B}, \mathrm{R}$ & Fr, L & M & $4,5,6,7,8,9,11$ \\
\hline Gelechiidae & Tildenia georgei Hoges & MI & $\mathrm{L}$ & $\mathrm{O}$ & 12 \\
\hline Gelechiidae & Tildenia inconspicuella (Murtfeldt) & MI & $\mathrm{L}$ & $\mathrm{O}$ & 12 \\
\hline Sphingidae & Manduca sexta (L.) & $\mathrm{C}$ & $\mathrm{L}$ & $\mathrm{O}$ & 1 \\
\hline Sphingidae & Manduca quinquemaculata Haw. & $\mathrm{C}$ & $\mathrm{L}$ & $\mathrm{O}$ & 1 \\
\hline \multicolumn{6}{|l|}{ Coleoptera } \\
\hline Mordellidae & Mordella atrata Melsheimer & $\mathrm{C}$ & $\mathrm{F} 1$ & $\mathrm{P}$ & 3 \\
\hline Chrysomelidae & Diabrotic undecimpunctata howardi Barber & $\mathrm{C}$ & $\mathrm{L}$ & $\mathrm{P}$ & 3 \\
\hline Chrysomelidae & Epitrix cucumeris Harr. & $\mathrm{C}$ & $\mathrm{L}, \mathrm{R}$ & $\mathrm{O}$ & 1 \\
\hline Chrysomelidae & Epitrix fuscula Crotch & $\mathrm{C}$ & $\mathrm{L}, \mathrm{R}$ & $\mathrm{O}$ & $1,2,3,16,19$ \\
\hline Chrysomelidae & Epitrix hirtipennis (Melsheimer) & $\mathrm{C}$ & $\mathrm{L}$ & $\mathrm{O}$ & 3,11 \\
\hline Chrysomelidae & Gratiana pallidula (Boheman) & $\mathrm{C}$ & $\mathrm{L}$ & $\mathrm{O}$ & $1,3,16$ \\
\hline Chrysomelidae & Leptinotarsa decemlineata (Say) & $\mathrm{C}$ & $\mathrm{L}$ & $\mathrm{O}$ & $2,9,10,11,15,16,17,18$ \\
\hline Chrysomelidae & Leptinotarsa juncta (Germar) & $\mathrm{C}$ & $\mathrm{L}$ & M & $11,15,19$ \\
\hline Curculionidae & Anthonomus eugenii Cano & $\mathrm{C}$ & $\mathrm{L}, \mathrm{Fr}, \mathrm{Fl}$ & $\mathrm{O}$ & 14 \\
\hline Curculionidae & Anthonomus nigrinus Bohneman & $\mathrm{C}$ & $\mathrm{Fl}$ & $\mathrm{O}$ & $3,16,20$ \\
\hline Curculionidae & Tricobaris trinotata (Say) & $\mathrm{B}$ & St & $\mathrm{O}$ & $1,3,13$ \\
\hline \multicolumn{6}{|l|}{ Diptera } \\
\hline Tephritidae & Zonosemata electa (Say) & $\mathrm{B}$ & $\mathrm{Fr}$ & $\mathrm{O}$ & 11 \\
\hline
\end{tabular}

${ }^{\text {a }}$ S: sapsucker, C: chewer, R: leaf roller, MI: leaf miner, and B: stem or fruit borer.

${ }^{\mathrm{b}} \mathrm{L}$ : leaf, St: stem, Fl: flower, Fr: fruit, R: root.

${ }^{\mathrm{c}} \mathrm{M}$ : specialist of $S$. carolinense (monophage); O: specialist of solanaceous plants (oligophage); P: generalist which feeds on plants of Solanaceae and other plant families (polyphage); ? not certain.

d 1. Somes (1916); 2. Ilnicki and Fertig (1962); 3. Burke (1963); 4. Solomon and McNaughton (1979); 5. Solomon (1980); 6. Solomon (1981); 7. Solomon (1983); 8. Solomon (1988); 9. Bailey and Kok (1982); 10. Hare and Kennedy (1986); 11. Bassett and Munro (1986); 12. Gross (1986); 13. Cuda and Burke (1986); 14. Patrock and Schuster (1992); 15. McCauley (1992); 16. Nichols et al. (1992); 17. Weber et al. (1995); 18. Mena-Covarrubias et al. (1996); 19. Wise and Sacchi (1996); 20. Clark and Burke (1996).

shoot density increased rapidly up to July, after which the increase was asymptotic. The maximum number of $7.16 \pm 5.16$ (s.d.) shoots per $\mathrm{m}^{2}$ was recorded on September 1. The shoot number decreased due to dying in late October when the temperature declined steeply.

Twenty arthropod species (species with * in Table 1), a total of 3,621 individuals, were recorded by the regular census in the NIAES field from May to October in 1992. The most abundant was E. vigintioctopunctata (34.0\% of the total) followed by Aulacorthum magnoliae (24.6\%), Trialeurodes vaporariorum (17.1\%), Thrips setosus (5.2\%), and Aphis gossypii (5.0\%). The top three species occupied more than $75 \%$ of the total number of individuals leading the community to low species diversity $\left(H^{\prime}=1.82 \pm 0.03\right.$ (95\% C.L.) nits).

The number of arthropods per shoot increased 


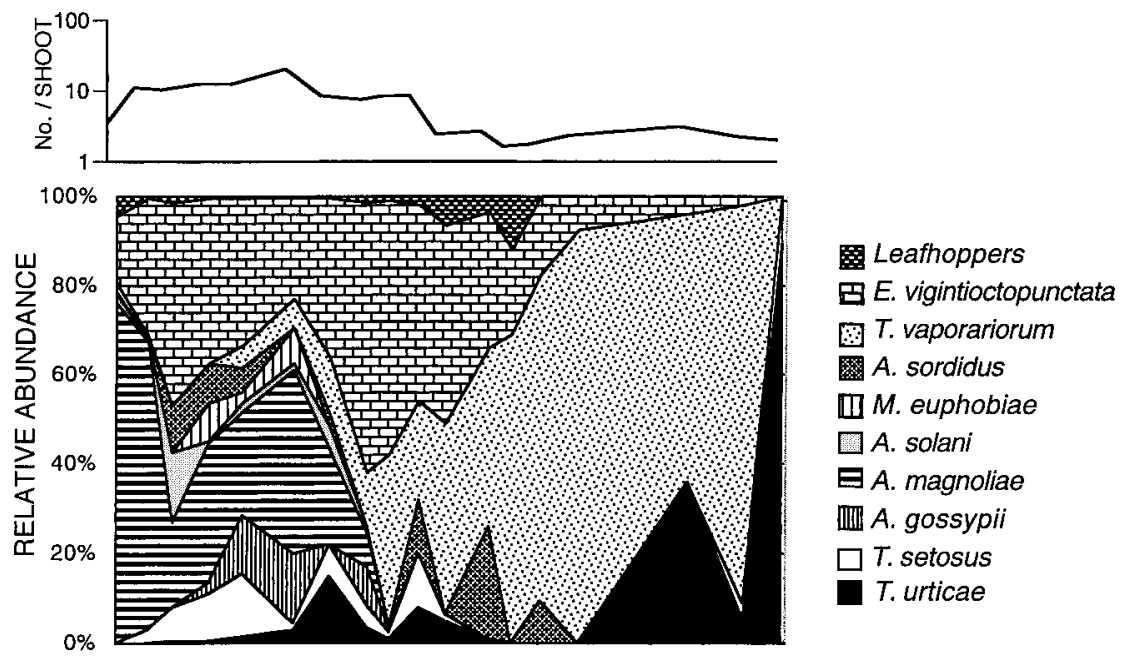

27 May 17 Jun 7 Jul 29 Jul 21 Aug 11 Sep 6 Oct 28 Oct

Fig. 3. Seasonal changes in total number of herbivorous arthropods per shoot (upper panel) and relative abundance of the top ten species (lower panel) in the regular census.

from May 27 and peaked at $20.5 \pm 23.5$ (s.d.) on July 7, after which the number declined, while the number was small from September 11 to October 28 (Fig. 3, upper panel). Figure 3 also indicates the seasonal change in relative abundance of the arthropod species (lower panel). Two generations of E. vigintioctopunctata occurred on S. carolinense in a year and the beetle was abundant throughout the growing season of the weed. $A$. magnoliae was relatively abundant from May to early July, whereas $T$. vaporariorum was dominant in the latter part of the season when most of other species disappeared or deceased.

\section{DISCUSSION}

Since the faunal comparisons of herbivores on $S$. carolinense in Japan and the USA were based on data of a different nature, the results should be interpreted cautiously. It can be, however, valid to discuss the following points.

The herbivorous arthropod community feeding on $S$. carolinense was dominated by polyphagous exophages in Japan (Table 1 and Fig. 2). Neither stem borers nor gall formers were found on $S$. carolinense in Japan. Similarly, Pueraria lobata, which is an endemic vine of Japan, had no monophagous or oligophagous borers and gall formers in the USA where the plant was introduced about 100 years ago (Carstensen and Imura, unpublished). The results supported the fact that a high proportion of exophages and polyphages are characteristic for young herbivore communities that feed on alien plants (Goeden, 1971b, 1974; Goeden and Ricker, 1982; Zwölfer, 1988; Wilson and Flanagan, 1990).

Two root feeders of flea beetles infested S. carolinense in the region of origin. Solanum nigrum L., which is estimated to have been introduced into Japan in a prehistorical era (Osada, 1976), was growing in adjoining areas in NIAES. A flea beetle, Psylliodes brettinghami Baly, that is a root and leaf feeder of solanaceous plants like the flea beetles in the USA, was infesting the $S$. nigrum plants abundantly, but it was never observed on S. carolinense. Root feeders that are harmful for perennial plants may take a longer time to colonize on alien plants than other herbivores. This inference is supported by other evidence that newly introduced alien plants were often free from root feeders (Wilson and Flanagan, 1990; Jobin et al., 1996). Additionally, there were no destructive flower and fruit feeders in the introduced region, suggesting that the reproductive parts of $S$. carolinense may tend to be unexploited niches of the herbivores.

As demonstrated in this study, alien weeds are frequently colonized by arthropod herbivores from other crops (Goeden, 1968; Zwölfer, 1988; Wilson and Flanagan, 1993). Most agricultural crops are alien plants artificially introduced from overseas in the past (Hoshikawa, 1988). Pest arthropods which are often polyphagous and adapt to crops growing 
in disturbed areas, viz. agricultural fields, must be easy to move onto alien weeds growing in the same environments.

Although 39 herbivorous arthropod species feeding on $S$. carolinense were recorded in this study, no more than 20 arthropod species were found on the local $S$. carolinense population by the intensive one-year regular census. Additionally, the arthropod community was dominated by only three species, resulting in the low species diversity of the community. Although the phenomenon whereby the communities on alien plants are dominated by only a few species and thus the diversity is low cannot be generalized at the present, Southwood et al. (1982) reported that the diversity of the herbivorous arthropod community was lower on introduced trees than on native trees in Britain and South Africa. The fact that limited herbivore species move on to the alien plants during the early colonization process (Strong et al., 1984) may be partly responsible for the low diversity.

Goeden (1971a, b), Hilgendorf and Goeden (1983) and Jobin et al. (1996) reported that alien plants suffered relatively little insect damage. The present faunal studies of $S$. carolinense suggested that the weed appears to escape from the arthropod herbivores to a certain extent in its vegetative and sexual reproduction parts in the introduced region. The regular census of the herbivorous arthropods, however, demonstrated that the density of a few species was high on the local $S$. carolinense population. The life cycle of the most dominant species, E. vigintioctopunctata, seemed to conform well to the phenology of $S$. carolinense. This species caused marked damage to the leaves; about $68 \%$ of the leaf area of the plant was destroyed mainly by the beetle infestation in early September (Imura, unpublished). Thus, whether or not $S$. carolinense is actually released from the herbivory of these endemic herbivores in the introduced region is unclear at present. Further quantitative studies are needed to evaluate the impact of herbivory by the arthropod herbivores on the growth and reproduction of the alien weed, $S$. carolinense.

\section{ACKNOWLEDGEMENTS}

I thank M. Hayashi, H. Ikemoto, F. Kadono, H. Katakura, T. Matsumura, M. Miyazaki, K. Yazaki, and S. Yoshimatsu for identification of the arthropod species. I also thank H. R. Burke, R. D. Goeden and T. Nishida for their information on the herbivores in the USA. N. Suzuki kindly gave invaluable comments on the earlier version of the manuscript. I am indebted to K. Kanie for her assistance in the field survey. This study was supported by the "Biocosmos Project" fund from the Ministry of Agriculture, Forestry and Fisheries, Japan.

\section{REFERENCES}

Asai, H. (1993) Green Invaders. Asahi Shimbun-Sha, Tokyo, $294 \mathrm{pp}$.

Bailey, T. E. and L. T. Kok (1982) Biology of Frumenta nundinella (Lepidoptera: Gelechiidae) on horsenettle in Virginia. Can. Entomol. 114: 139-144.

Bassett, I. J. and D. B. Munro (1986) The biology of Canadian weeds. 78. Solanum carolinense L. and Solanum rostratum Dunal. Can. J. Plant Sci. 66: 977-991.

Blossey, B. and R. Nötzold (1995) Evolution of increased competitive ability in invasive nonindigenous plants: a hypothesis. J. Ecol. 83: 887-889.

Burke, H. R. (1963) Coleoptera associated with three species of Solanum in Texas. Southw. Nat. 8: 53-56.

Clark, W. E. and H. R. Burke (1996) The species of Anthonomus Germar (Coleoptera: Curculionidae) associated with plants in the family Solanaceae. Southw. Entomol. Supplement No. 19: 114 pp.

Cousens, R. and M. Mortimer (1995) Dynamics of Weed Populations. Cambridge Univ. Press, Cambridge. 332 pp.

Crawley, M. J. (1987) What makes a community invasible? In Colonization, Succession and Stability (M. J. Crawley and P. D. Edwards eds.). Blackwell Sci., Oxford, pp. 429-453.

Crawley, M. J. (1997) Biodiversity. In Plant Ecology (M. J. Crawley ed.). Blackwell Sci., Oxford, pp. 595-632.

Cuda, J. P. and H. R. Burke (1986) Reproduction and development of the potato stalk borer (Coleoptera: Curculionidae) with notes on field biology. J. Econ. Entomol. 79: $1548-1554$.

Enomoto, T. (1999) Naturalized weeds from foreign countries into Japan. In Biological Invasions of Ecosystem by Pests and Beneficial Organisms (E. Yano, M. Matsuo, M. Shiyomi and D. A. Andow eds.). National Institute of Agro-Environmental Sciences, Tsukuba, pp. 1-14.

Goeden, R. D. (1968) Russian thistle as an alternate host to economically important insects. Weed Sci. 16: 102-103.

Goeden, R. D. (1971a) Insect ecology of silverleaf nightshade. Weed Sci. 19: 45-51.

Goeden, R. D. (1971b) The phytophagous insect fauna of milk thistle in southern California. J. Econ. Entomol. 64: 1101-1104.

Goeden, R. D. (1974) Comparative survey of the phytophagous insect faunas of Italian thistle, Carduus pycnocephalus, in southern California and southern Europe relative to biological control. Environ. Entomol. 3: 464-474.

Goeden, R. D. and D. W. Ricker (1982) Poison hemlock, Conium maculatum, in southern California - an alien weed attacked by few insects. Ann. Entomol. Soc. Am. 75: 173-176.

Gross, P. (1986) Life histories and geographic distributions of two leaf miners, Tildenia georgei and T. inconspicuella 
(Lepidoptera: Gelechiidae), on solanaceous weeds. Ann. Entomol. Soc. Am. 79: 48-55.

Hare, J. D. and G. G. Kennedy (1986) Genetic variation in plant-insect associations: survival of Leptionotarsa decemlineata populations on Solanum carolinense. Evolution 40: 1031-1043.

Harper, J. L. (1965) Establishment, aggression, and cohabitation. In The Genetics of Colonizing Species (H. G. Baker and G. L. Stebbins eds.). Academic Press, New York, pp. 243-268.

Hilgendorf, J. H. and R. D. Goeden (1983) Phytophagous insect faunas of spiny clotbur, Xanthium spinosum, and cocklebur, Xanthium strumarium, in southern California. Environ. Entomol. 12: 404-411.

Hoshikawa, K. (1988) Origin and Spread of Cultivated Plants. Ninomiya Shoten, Tokyo, 295 pp.

Ilnicki, R. D. and S. N. Fertig (1962) Life history studies as related to weed control in the Northeast. 3. Horse Nettle. Road Island Agr. Exp. Stat. Bull. 368: 54 pp.

Imura, O. and S. Ninomiya (1998) Quantitative measurement of leaf area consumption by Epilachna vigintioctopunctata (Fabricius) (Coleoptera: Coccinellidae) using image processing. Appl. Entomol. Zool. 33: 491-495.

Japanese Society of Applied Entomology and Zoology (ed.) (1987) Major Insect and Other Pests of Economic Plants in Japan. Japan Plant Protection Association, Tokyo. 379 pp.

Jobin, A., U. Schaffner and W. Nentwig (1996) The structure of the phytophagous insect fauna on the introduced weed Solidago altissima in Switzerland. Ent. Exp. Appl. 79: 33-42.

Keane, M. and M. J. Crawley (2002) Exotic plant invasions and the enemy release hypothesis. Trends Ecol. Evol. 17: $164-170$.

Krebs, J. R. (1999) Ecological Methodology. 2nd ed. Addison Wesley Longman, Menlo Park. 620 pp.

McCauley, D. E. (1992) Family structured patterns of mortality in false Colorado potato beetle. Ecol. Entomol. 17: $142-148$.

Mena-Covarrubias, J., F. A. Drummond and D. L. Haynes (1996) Population dynamics of the Colorado potato beetle (Coleoptera: Chrysomelidae) on horsenettle in Michigan. Environ. Entomol. 25: 68-77.

Nichols, R. L., J. Cardina, R. L. Lynch, N. A. Minton and H. D. Wells (1992) Insects, nematodes, and pathogens associated with horsenettle (Solanum carolinense) in bermudagrass (Cynodon dactylon) pastures. Weed Sci. 40: 320-325.

Nishida, T., N. Kitahara, N. Harashima, O. Watanabe and S. Shibata (1999) Factors affecting presence of horsenettle (Solanum carolinense L.) in pastures of central Japan. $J$. Weed Sci. Tech. 44: 356-360.
Osada, T. (1976) Colored Illustrations of Naturalized Plants of Japan. Hoikusha Publ. Co. Ltd., Osaka. 425 pp.

Patrock, R. J. and D. J. Schuster (1992) Feeding, oviposition and development of the pepper weevil, (Anthonomus eugenii Cano), on selected species of Solanaceae. Trop. Pest Manag. 38: 65-69.

Sokal, R. R. and F. J. Rohlf (1995) Biometry. 3rd ed. W. H. Freeman and Company, New York. 887 pp.

Solomon, B. P. (1980) Frumenta nundinella (Lepidoptera: Gelechiidae): life history and induction of host parthenocarpy. Environ. Entomol. 9: 821-825.

Solomon, B. P. (1981) Response of a host-specific herbivore to resource density, relative abundance, and phenology. Ecology 62: 1205-1214.

Solomon, B. P. (1983) Compensatory production in Solanum carolinense following attack by a host-specific herbivore. J. Ecol. 71: 681-690.

Solomon, B. P. (1988) Infestation of Solanum carolinense fruit by Frumenta nundinella: Are larvae affected by interfruit competition? Am. Midl. Nat. 119: 7-14.

Solomon, B. P. and S. J. McNaughton (1979) Numerical and temporal relationships in a three-level food chain. Oecologia 42: 47-56.

Somes, M. P. (1916) Some insects of Solanum carolinense L., and their economic relations. J. Econ. Entomol. 9: $39-44$.

Southwood, T. R. E., V. C. Moran and C. E. J. Kennedy (1982) The richness, abundance and biomass of the arthropod communities on trees. J. Anim. Ecol. 51: 635-649.

Strong, D. R., J. H. Lawton and R. Southwood (1984) Insects on Plants. Blackwell Sci. Publ., Oxford. 313 pp.

Tilman, D. (1999) The ecological consequences of changes in biodiversity: a search for general principles. Ecology 80: 1455-1474.

Weber, D. C., F. A. Drummond and D. N. Ferro (1995) Recruitment of Colorado potato beetles (Coleoptera: Chrysomelidae) to solanaceous hosts in the field. Environ. Entomol. 24: 608-622.

Wilson, C. G. and G. J. Flanagan (1990) The phytophagous insect fauna of the introduced shrubs Sida acuta Burm. F. and Sida cordifolia L. in the Northern Territory, Australia. Aust. ent. Mag. 17: 7-15.

Wilson, C. G. and G. J. Flanagan (1993) Phytophagous insect fauna of the introduced noxious weed Xanthium occidentale in northern Australia and its relevance to biological control. Environ. Entomol. 22: 254-261.

Wise, M. J. and C. F. Sacchi (1996) Impact of two specialist insect herbivores on reproduction of horse nettle, Solanum carolinense. Oecologia 108: 328-337.

Zwölfer, H. (1988) Evolutionary and ecological relationships of the insect fauna of thistles. Annu. Rev. Entomol. 33: 103-122. 